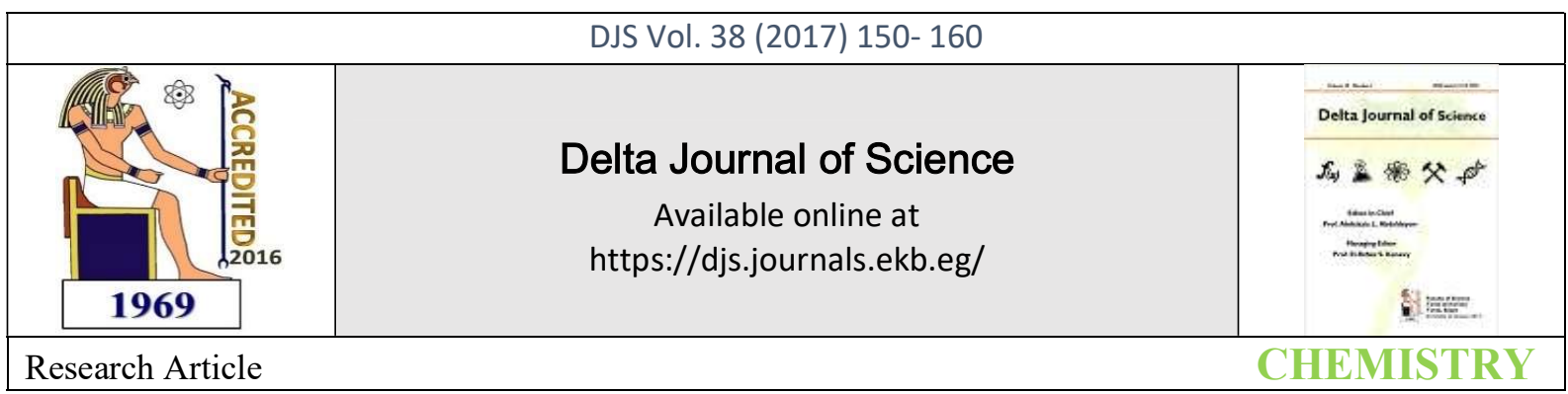

\title{
Study the Hemolytic and Cytotoxic Effects of Saponin Isolated from Soy Bean.
}

\author{
Mai M. El-Keiy, Aliaa M. Radwan* and Tarek M. Mohamed \\ Department of Chemistry, Fac. of Science, Tanta University, Tanta, Egypt
}

\begin{abstract}
Saponin is an important class of natural products that can be found primarily in many plants, as well as in some marine animals. It has a diverse range of properties, which include pharmacological and medicinal properties, strong hemolytic properties, as well as antimicrobial, insecticidal, and anticancer activities. Our study aimed to isolate the saponin from different plant sources (legumes) and to evaluate its hemolytic and cytotoxic activity in higher plant source. In this study the saponin was extracted from legumes using choloroform and ethanol. The concentration of saponin was determined by colorimetric method. Soybean saponin source was loaded on silica gel column chromatography and was detected by thin layer chromatography (TLC), infrared spectroscopy (IR) and confirmed by high performance liquid chromatography (HPLC). In addition the hemolytic activity of soybean saponin was evaluated on human blood erythrocyte and the cytotoxic effect on human colon cancer cell line (Coca) was determined by using MTT assay. Our result showed the presence of blue violet spot on thin layer chromatography in soya been saponin and confirmed by IR spectrum by presence of C-H bond of at $2927 \mathrm{~cm}^{-1}$, C$\mathrm{O}$ stretching at $1059 \mathrm{~cm}^{-1}, \mathrm{C}=\mathrm{C}$ bond at $1628 \mathrm{~cm}^{-1}$ and $\mathrm{OH}$ bond at $3400 \mathrm{~cm}^{-1}$. Hemolytic dose (HD50) that made hemolysis for $50 \%$ of erythrocyte was $0.412 \mathrm{mg} / \mathrm{ml}$. MTT assay releaved that saponin extracted from soya bean had $\mathrm{IC}_{50} 43.4 \mu \mathrm{g} / \mathrm{ml}$ against colon cancer cell line in $48 \mathrm{hr}$ treatment. In conclusion, Soya saponin inhibits the proliferation of colon cancer and thus it may have therapeutic application in future.
\end{abstract}

Key words: soybean, saponin, hemolysis, colon cancer.

\section{Introduction:}

For thousands of years natural products have played a very important role in health care and prevention of diseases (Phillipson, 2001). Natural products, which are a rich source of compounds with enormous structural diversity, have been extensively explored in the field of drug discovery and have led to remarkable successes. This is particularly evident in the field of cancer therapeutics, where over $50 \%$ of the approved drugs discovered in the last two decades of the 20th century were of natural origin (Newman et al., 2002).

Legumes play an important role in the traditional diets of many regions throughout the world especially soybean because it is a concentrated source of isoflavones, phytosterols, phytates and saponins and thus it has received considerable attention for their 
potential role in preventing and treating cancer (Messina and Barnes, 1991).

The name 'saponin' is derived from the Latin word sapo, which means 'soap', because saponin molecules form soap-like foams when shaken with water due to the combination of hydrophilic and lipophilic properties (Gepdiremen et al., 2005).

Saponins are one of the groups of secondary metabolites and it is generally composed of triterpenoid or steroid aglycone moiety with complex substituent of oligosaccharide (Adiukwu et al., 2013). These saponins are heterogeneous or diverse group of glycosides which is produced mainly by medicinal plants or natural products and also by lower marine animals and some bacteria (Gepdiremen et al., 2005). The presence of both polar (sugar) and non-polar (steroid or triterpene) groups provide saponins with strong surface-active properties which then are responsible for many of its adverse and beneficial biological effects such as hemolytic and anticancer properities (Zhao et al., 2008). The haemolytic action of saponins is believed to be the result of the affinity of the aglycone moiety for membrane sterols, particularly cholesterol, with which they form insoluble complexes (Man et al., 2010).

Differences in saponin structure which include the type, position, and number of sugar moieties attached by aglycosidic bond at different positions of the rings can characteristically influence biological responses, especially for the antitumor activity so the antitumor effect of saponin worked through various pathways, such as anti-cancer, anti-metastatic, immunostimulation and chemoprevention (Bachran $\boldsymbol{e t}$ al., 2008).. Hence this study is aimed to evaluate saponin from Egyptian plant sources for hemolytic and cytotoxic activity.

\section{Material and methods:}

\section{Plant materials:}

Legumes: bean (Vicia faba), soybean (Glycine max), cowpeas (Vigna unguiculata), chichpea (Cicer arietinum), kidney beans (Phaseolus vulgaris) and lupine (Lupinus albus L.), which were purchased from Tanta market, Egypt.

\section{Chemicals:}

Standard saponin was purchased from Fisher Scientific, UK. Silica gel (60-200 mesh size) was purchased from Loba chemie, Mumbai, India. DPPH (2,2 diphenyl-1-picrylhydrazyl), (3- $(4$, 5dimethylthiazol-2-yl)-2, 5-diphenyltetrazolium bromide) (MTT) and dimethyl sulfoxide (DMSO) were purchased from Sigma-Aldrich, USA. All other chemicals used were of high grade.

\section{Extraction and determination of saponin from} legumes:
A modified method of Tani et al. (1985) was used. Samples were ground and defatted with chloroform in a soxhlet apparatus to remove the interfering pigments and lipids. $50 \mathrm{~g}$ of the defatted sample were re-extracted with $250 \mathrm{ml}$ of $95 \%$ ethanol (volume enough to make reflux) in a soxhlet extractor and the source of heating was water bath at $75^{\circ} \mathrm{c}$ (the boiling point of ethanol )for $16 \mathrm{hrs}$ or till the color of the solvent in the thimble became colorless. The ethanolic extract was then concentrated by evaporation of the solvent using rotary evaporator under reduced pressure. The concentrated extract was then precipitated using excess volume of acetone. The resulting precipitate was filtered and dried to give crude saponin mixture then calculated the saponin mass.

(Yield) $\% \mathrm{SP}=\mathrm{A} / \mathrm{SM}$,

While A is the mass of saponin and SM is the sample mass (per gram).

4. Colorimetric method for quantification analysis of saponin:

The determination of total content of triterpenoid saponins was performed according to the method of (Xiang et al., 2001) and (Yoko et al., 2000) using standard saponin.

Ten $\mathrm{mL}$ of $2 \mathrm{M} \mathrm{HCl}$ was added to $10 \mathrm{~mL}$ ethanol solution of saponin and hydrolyzed for $3 \mathrm{~h}$ at $90^{\circ} \mathrm{C}$, cooled, and extracted twice with $80 \mathrm{~mL}$ diethyl ether. The saponin fraction in the ether layer was isolated and the ether was removed under reduced pressure and the residue which contained sapogenin was dissolved with ethyl acetate and made up to $10 \mathrm{~mL}$ for spectrophotometry. $10 \mu 1$ of hydrolyzed saponin from each sample completed to $0.6 \mathrm{ml}$ and was determined by adding $0.2 \mathrm{ml}$ mixture of $5 \%$ vanillin-acetic acid (weight per volume) and $1.2 \mathrm{ml}$ of perchloric acid, the mixture was incubated at $70^{\circ} \mathrm{c}$ for $15 \mathrm{~min}$. After that the tubes were taken out and cooled in running water for $2 \mathrm{~min}$. then, ethyl acetate was added in order to make the total volume being $5 \mathrm{ml}$. Blank solution of acetic acid was used as reference, the absorbence was measured at $550 \mathrm{~nm}$.

The standared curve was ranged from $(0.1-1 \mathrm{mg} / \mathrm{ml})$ and the concentration of saponin extracted from different legumes was calculated according to the following equation:

$$
A=0.75 C\left(R^{2}=0.9933\right)
$$

\section{Chromatographic analysis:}

\subsection{Column chromatography:}

A silica gel column (60-200 mesh) was used for soybean saponin purification. Concentrated crude saponin sample was applied to the column. The impurities were washed with n-hexane: ethanol (1:1) 
(two bed volume) through a $12 \times 6 \mathrm{~cm}$ bed of silica gel. The column was eluted with $n$-butanol/ ethanol/water (1:1:1). The flow rate was $4 \mathrm{ml} / 5 \mathrm{~min}$ and the total bed volume was $144 \mathrm{ml}$. Fractions $(4 \mathrm{ml})$ were collected. Aliquots from fractions were applied to a strip of TLC plate and the concentration of saponin was determined in each fraction (Khalil and El-Adawy, 1994)

\subsection{Thin-layer chromatography (TLC):}

TLC analysis was carried out on aluminium plates coated with silica gel 60 (Merk KGaA Darmstadt, Germany) according to the method of (Kerem et al., 2005). $10 \mu 1$ of the solution of the standard saponin, saponin enriched extracts from different legumes and soybean saponin after column chromatography were applied on TLC paper and the plate was developed in the solvent system n-butanol: water: acetic acid (84:14:7) to a distance of $15 \mathrm{~cm}$ from the origin. The developed plate was dried in the air. TLC plate after development and drying was sprayed with freshly prepared solution of ethanol :sulphuric acid (90:10).After spraying the plate was heated at $110^{\circ} \mathrm{c}$ for 10 minutes.

\section{Fourier transform infrared (FTIR):}

Positive fractions from column chromatography were pooled then the solvent was evaporated and the sample was dried. The sample and standard saponin were ground to quite powder with mesh sieve and mixed $1 / 1$ with vacuum dried $\mathrm{KBr}$ powder to make compressed pellet with subsequent recording of infrared spectrum. A JNS-CO Spectrum System 4100 LE FTIR spectrometer (Japan) was used for the analysis in the range between $4000 \mathrm{~cm}-1$ and 400 $\mathrm{cm}-1$ at a resolution of $4 \mathrm{~cm}-1$ (Amini et al., 2014)

7. High performance liquid chromatography

(HPLC):

Saponin from soybean was confirmed and quantified after column chromatography by using YL9100 HPLC system, Japan (C18 column) according to the method of (Snyder et al., 1997). 20 milligrams of dried soy sample was dissolved in $1 \mathrm{ml}$ of $80 \%$ HPLC grade aqueous methanol and used for HPLC analysis. The mobile phases were $0.05 \%$ trifluoroacetic acid in water (solvent A) and acetonitrile (solvent B). The column temperature was $30{ }^{\circ} \mathrm{C}$. The injection volume was $50 \mu 1$. The flow rate was $1 \mathrm{~mL} / \mathrm{min}$. The UV absorbance was monitored at $205 \mathrm{~nm}$. The concentration of saponin in soybean was calculated by using standard saponin as reference. The results were expressed as milligrams of soyasaponin per gram of soy sample.

8. Determination of hemolytic activity of soybean saponin:
The hemolytic activity of soybean saponin was measured on the basis of method of (Hassan et al., 2010). Human blood was obtained and collected on heparin. Separation of human erythrocyte were performed by centrifugation at $4000 \mathrm{rpm}$ for $5 \mathrm{~min}$. The obtained pellet was washed three times with PBS and $2 \%$ erythrocyte suspension was used for assessment hemolytic activity. The concentration of soybean saponin that were used for evaluation of hemolytic activity were prepared in PBS as follow(0.1, $0.3,0.5,0.7,0.9,1.1$ and $1.3 \mu \mathrm{g} / \mathrm{ml})$ which were incubated with $2 \mathrm{ml}$ of $2 \%$ erythrocyte suspension for $1 \mathrm{hr}$ at room temperature. Saline and distilled water were included as minimal and maximal hemolytic controls. The hemolytic percent developed by the saline control was subtracted from all groups. the samples were centrifuged at $4000 \mathrm{rpm}$ for $10 \mathrm{~min}$ and the free hemoglobin in the supernatant was measured spectrophotometrically at $412 \mathrm{~nm}$.

\section{Evaluation of cytotoxic effect of soybean saponin:}

\section{Cell line and culture}

Human colon cancer cell (Coca) line was obtained from institution Serum and Vaccine, Cairo. Coca cells were maintained in DMEM (Dulbecco's Modified Eagle Medium) containing 10\% fetal bovine serum (FBS) with $100 \mathrm{U} / \mathrm{mL}$ of penicillin and 100 $\mathrm{lg} / \mathrm{mL}$ of streptomycin in $5 \% \mathrm{CO} 2$ at $37^{\circ} \mathrm{C}$. Cells were maintained at a concentration between $2 \times 10^{5}$ and 1 $\mathrm{x} 10^{6}$ cells $/ \mathrm{mL}$. Cells were subcultured every 2-3 days by total media replacement using trypsin -EDTA. Viable cells were assessed by $0.04 \%$ trypan blue exclusion dye using a hemocytometer.

\section{MTT assay}

The effect of soybean saponin on Coca cells viability was determined using the MTT assay .Coca cells were seeded in 96-well plate at final concentration $1 \times 10^{4}$. After incubation overnight, the cells were treated with or without different concentration of soyasaponin $(10.20,40,60,80$ and $100 \mu \mathrm{g} / \mathrm{ml}) .48 \mathrm{~h}$ later, $50 \mu \mathrm{l}$ of MTT stock solution $(2 \mathrm{mg} / \mathrm{ml})$ was added and after incubation for $4 \mathrm{~h}$, the supernatant from each well was removed and the formazen crystals formed by viable cells were dissolved with DMSO $(150 \mu 1 /$ well $)$ with shaking (at highest speed) for $15 \mathrm{~min}$ at room temperature. The absorbance was read with a microplate reader at $540 \mathrm{~nm}$.

The cytotoxicity was evaluated with reference to the IC50 value. The tests were performed 3 independent times (Zhang and Popovich, 2008)

\section{Results}


The obtained results in table (1) showed that the total concentrations of saponin in soybean, lupine, cowpea, chickpea, kidneybean and bean were 94.89, $20.77,13.23,10.59,6.18$ and $5.7 \mathrm{mg} / \mathrm{g}$ dry weight respectively.

In addition, TLC analysis showed the presence of blue violet spot in each extract with $\mathrm{Rf} 0.4$ after the plate was sprayed with ethanol: sulfuric acid (90:10), Fig. (1). The soybean extract that contain the highest saponin concentration was partially purified using silica gel column chromatography and the fractions were confirmed of the presence of saponin by TLC then the positive fractions which appeared the presence of blue violet spots without impurities Fig. (3) were pooled and the concentration of saponin after pooling was determined compared to before the column, the data showed that the concentration of the pooled saponin was $1671.32 \mathrm{mg}$ with yield percent $56.36 \%$ as shown in Table (2).

The FTIR spectrum of purified soybean saponin releaved the presence of $\mathrm{C}-\mathrm{H}$ bond at $2927 \mathrm{~cm}-1$, C-O$\mathrm{C}$ bond at $1052 \mathrm{~cm}-1, \mathrm{C}=\mathrm{C}$ bond at $1628 \mathrm{~cm}-1$ and $\mathrm{OH}$ bond at $3400 \mathrm{~cm}-1$ were assigned in Fig. (4) as compared with standard saponin. Also, HPLC analysis releaved the presence of saponin in soybean with concentration $20.5 \mathrm{mg} / \mathrm{gm}$ dry weight. Fig. (5) and (6) showed the chromatogram of standard saponin and soybean saponin with retention time 1.7 and 1.8 respectively. There were other peaks with different retention times but with lower concentrations.

The soybean saponin was screened for its hemolytic activity when the human blood erythrocytes were incubated with different concentrations of soybean saponin for $1 \mathrm{~h}$ and the free hemoglobin was measured. The results releaved that soybean saponin had the ability to hemolyze the human blood erythrocyte with HD50 $0.412 \mathrm{mg} / \mathrm{ml}$ as in Fig. (7).

Fig. (8) showed the effect of standard and soybean saponin on Coca cell viability which releaved that the treatment of colon cancer cells with standard saponin and soybean saponin at a concentration $10 \mu \mathrm{g} / \mathrm{ml}$ for each for $48 \mathrm{~h}$, the viability of cells were 75.8 and $85.5 \%$ respectively. When the concentrations of standard and soybean saponin increased, the viability of colon cancer cells significantly $(<0.01)$ decreased with $\mathrm{IC}_{50} 28.7$ and $43.4 \mu \mathrm{g} / \mathrm{ml}$ for standard and soybean saponin.

Table 1. The concentration of saponin in different legumes

\begin{tabular}{|c|c|c|c|}
\hline Legumes & $\begin{array}{c}\text { Concentration } \\
\text { of triterpenoid } \\
\text { saponin } \\
(\mathrm{mg} / \mathrm{ml})\end{array}$ & $\begin{array}{l}\text { Concentration of } \\
\text { triterpenoid } \\
\text { saponin (mg/g } \\
\text { dry weight) }\end{array}$ & $\begin{array}{c}\% \\
\text { Yield }\end{array}$ \\
\hline Soybean & 185.33 & 94.89 & $5.12 \%$ \\
\hline Lupine & 45.96 & 20.77 & $4.5 \%$ \\
\hline Cowpea & 82.71 & 13.23 & $1.6 \%$ \\
\hline chickpea & 57.6 & 10.59 & $1.84 \%$ \\
\hline kidneybean & 35.16 & 6.18 & $1.42 \%$ \\
\hline Bean & 55.4 & 5.7 & $1.04 \%$ \\
\hline
\end{tabular}

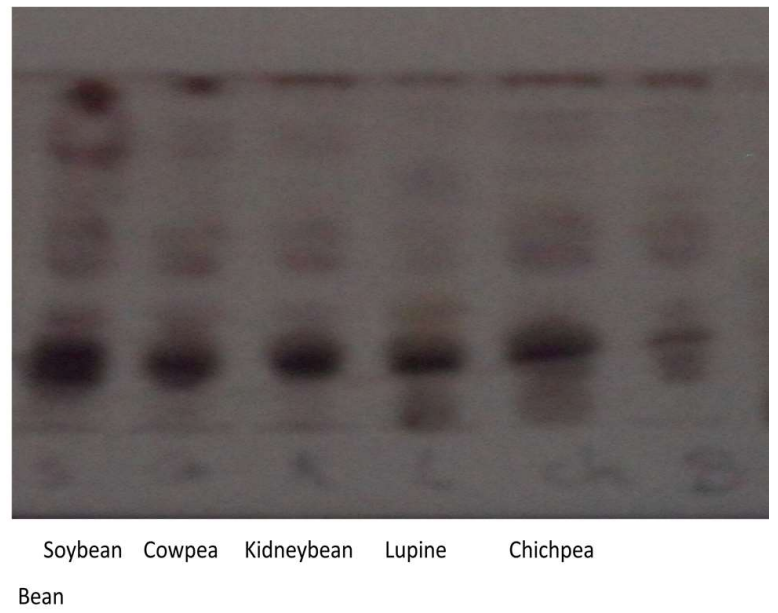

Fig (1): Thin layer chromatography of crude saponin extracted from different legumes

Table 2. Purification scheme of soyabean saponin 


\begin{tabular}{|c|c|c|c|c|}
\hline Step & $\begin{array}{c}\text { Concentrati } \\
\text { on of } \\
\text { saponin } \\
\text { (mg/ml) }\end{array}$ & $\begin{array}{c}\text { Volume } \\
\text { (ml) }\end{array}$ & $\begin{array}{c}\text { Total } \\
\text { concentratio } \\
\text { n of saponin } \\
\text { (mg) }\end{array}$ & \%yield \\
\hline $\begin{array}{c}\text { 1.Crude } \\
\text { extract }\end{array}$ & 185.33 & 16 & 2965.28 & $100 \%$ \\
\hline $\begin{array}{c}\text { 2. Silica gel } \\
\text { column } \\
\text { chromatogr- } \\
\text { aphy }\end{array}$ & 34.82 & 48 & 1671.36 & $56.36 \%$ \\
\hline
\end{tabular}

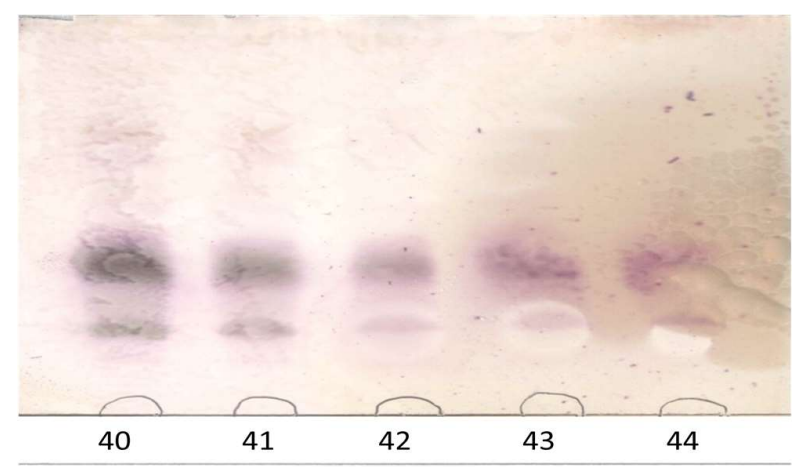

Fig. (2): Thin layer chromatography of soybean saponin after column chromatoraphy.

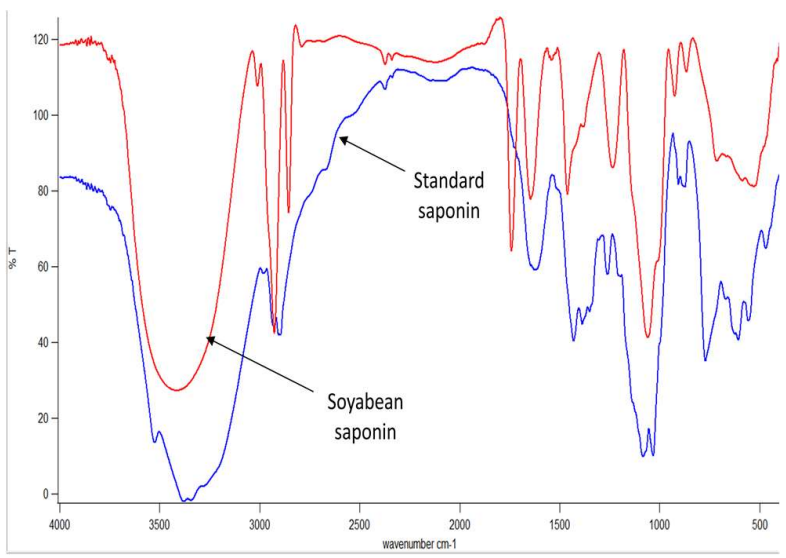

Fig. (3): FTIR spectrum of standard saponin and soybean saponin

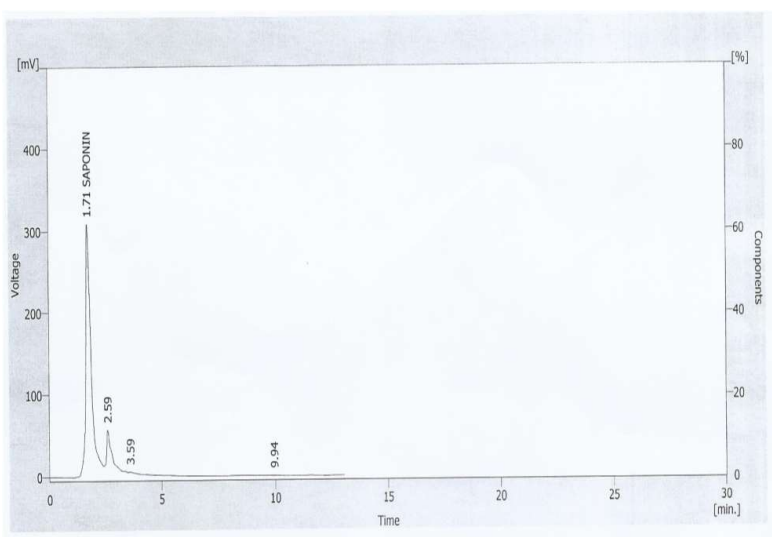

Fig. (4): HPLC chromatogram of standard saponin

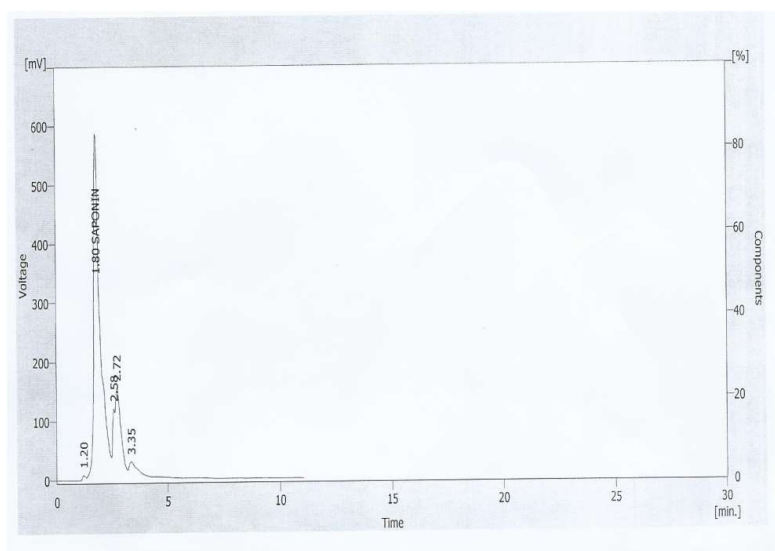

Fig. (5) : HPLC chromatogram of soybean saponin 


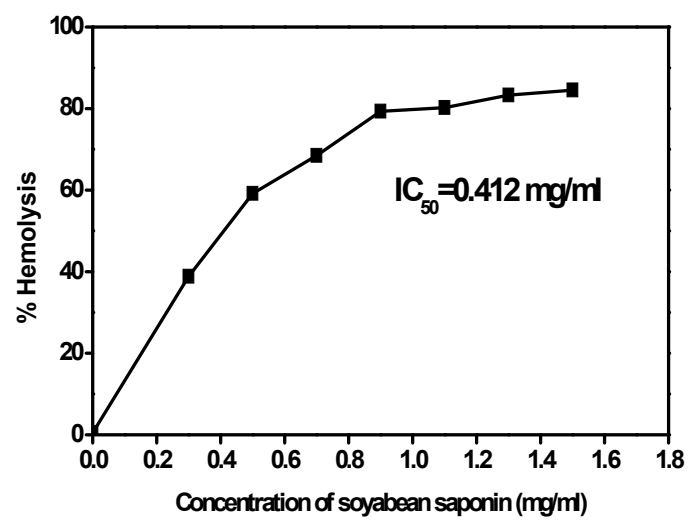

Fig. (6): Hemolytic activity of soybean saponin

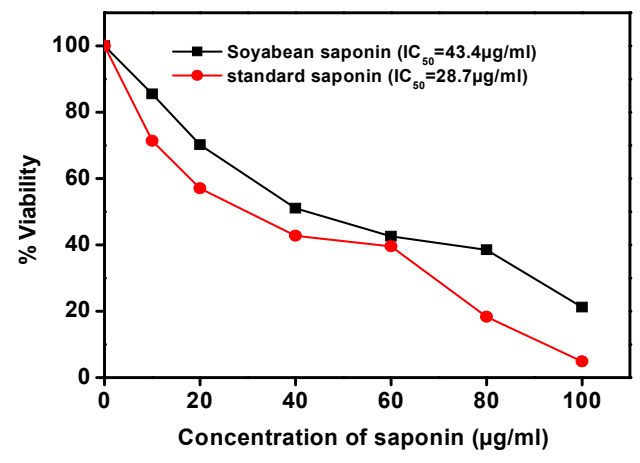

Fig. (8): Effect of standard saponin and soybean saponin on Coca cell viability by the MTT assay after $48 \mathrm{~h}$ incubation. The mean percent of control ( \pm standard deviation) was calculated for each cell viability and compared with the viability of untreated cell, which was considered to corresponding $100 \%$ viability

\section{Discussion:}

In the past, legumes were consumed as the main staplefoods in traditional dietary patterns; they are rich in high-biological value proteins, bioactive peptides, essential amino acids and other bioactive compounds such as functional fatty acids, isoflavones, phenolic acids and saponins (Messina, 1991; Zahra and Parvin, 2015)
Saponins are the main bioactive compounds that exhibit a wide range of biological activities and have many therapeutic effects (Sottorff et al., 2013). These compounds have been studied in many plant sources and also in some marine animals. For example, Silchenko et al. (2008) identified saponins in Mediterranean, North Atlantic, and North Pacific sea cucumber species.

Hu et al., 2002 extracted and isolated saponin from soybean, they found that the soyasaponin concentration and composition varied in soybeans, soy foods, and soy ingredients and this may depend on the variety of soybeans and the processing conditions used to produce a particular product.

In the present study, saponins were extracted using ethanol followed by precipitation using excess volume of acetone. The main saponin that present in legumes are soya saponins which are triterpenoid saponin of oleanan type so the determination of total triterpenoid saponin content in crude legumes extract was performed by colorimetric method of Xiang et al. (2001). Soya bean was the richest source of saponin with concentration $185.3 \mathrm{mg} / \mathrm{ml} \pm 0.77$. The concentration of saponin in soya bean was higher than previously reported by Murakami et al. (2013) who extracted saponin from Ilex paraguariensis St. Hil and determined its concentration was $0.366 \mathrm{mg} / \mathrm{ml} \pm 14.01$ and Pasaribu et al. (2014) who determined the concentration of saponin extracted from Sapindus rarak Pericarp which was $40.27 \mathrm{mg} / \mathrm{ml}$. The other five legumes, lupine, cowpea, chickpea, kidney bean and bean were 45.96, 82.71, 57.6, 35.16 and $55.4 \mathrm{mg} / \mathrm{ml}$, respectively.

In this study TLC was applied to confirm the presence of saponin in different legumes extracts as simple and qualitative method. In the present study, saponin extract from lupine, cowpea, chickpea, kidney bean bean and soybean before applying to the column has been separated into six fractions. Khalil and ElAdawy (1994) showed that saponin extract from peas and soybean has been separated into seven and six fractions each. The obtained results showed that there are violet spots in each extract with $R_{\mathrm{f}}$ value 0.4 when the plate was sprayed with ethanol and sulfuric acid. These results are nearly in accordance with the results reported by Jamuna and Subramanium, (2014) and Payal et al. (2010) when they extracted saponin from the leaf of Hypochaeris radicata L and Sesbania 
sesban (L.) Merr in which TLC showed violet spots with $\mathrm{R}_{\mathrm{f}}$ values 0.56 and 0.61 respectively by using methanol and chloroform as solvent system.

Column chromatography is a method used to purify individual compounds from mixtures of compounds in biology and biochemistry. Silica gel is the most common solid adsorbents that used in column chromatography (Ranjith et al., 2014). In this study, the soybean saponin was separated and partially purified from soybean crude extract using silica gel column chromatography. Saponin from soybean after elution showed blue violet spots without impurities after running with TLC plate. The results showed that $\mathrm{Rf}$ of soybean from thin layer after elution from silica gel column was 0.4 as before elution.

Fourier transform infrared spectroscopy (FTIR) technique was performed as highly specific method for saponin identification. Recognition of saponin in soybean after partial purification with silica gel column chromatography was confirmed by infrared absorptions recorded. FTIR spectrum of the reference sample and partial purified soybean saponin indicated characteristic absorbtion peaks of saponin. It showed the presence of the long sharp peak at $3400 \mathrm{~cm}^{-1}$ indicates the presence of hydroxyl groups $(-\mathrm{OH})$ and the peak at $2927 \mathrm{~cm}^{-1}$ represents alkyl groups $(\mathrm{C}-\mathrm{H})$. ($\mathrm{C}=\mathrm{C})$ groups at $1628 \mathrm{~cm}^{-1}$. C-O-C bond at $1052 \mathrm{~cm}^{-1}$. Existence of $-\mathrm{OH}, \mathrm{C}-\mathrm{H}$, and $\mathrm{C}=\mathrm{C}$ bands in absorptions peak of FTIR spectrum was characteristic of saponins. The C-O-C absorptions indicated glycoside linkages to the sapogenins. Therefore, FTIR spectra represented indicative sign of presence saponin like compounds in soybean (Kareru et al., 2008).

Some studies were used FTIR for saponin characterization. For instance, Amini et al. in 2014 performed FTIR spectroscopy for direct identification of saponin like compounds isolated from Persian Gulf brittle star (Ophiocoma erinaceus) which revealed the presence of broad and strong signal of hydroxyl group (339 $\left.8.78 \mathrm{~cm}^{-1}\right), \mathrm{C}-\mathrm{H}\left(2851.54 \mathrm{~cm}^{-1}\right)$, signal olefinic $(\mathrm{C}=\mathrm{C})\left(\begin{array}{ll}167 & 3.33 \mathrm{~cm}^{-1}\end{array}\right)$, strong absorption signals sulfate group (C-O-C) noted at $1213.97 \mathrm{~cm}^{-1}, 105$ $5.14 \mathrm{~cm}^{-1}$.

The partial purified soybean saponin was identified on reverse phase high performance liquid chromatography. Due to their poor chromophores, most of the soybean triterpenoid saponins can only be detected at wavelength of $205 \mathrm{~nm}$ which indicated that the peaks obtained before 5 minutes were saponins as compared with the standard. In HPLC chromatogram of standard and soybean saponin there were high peaks obtained at retention time 1.7 and 1.8 respectively with concentration $20.6 \mathrm{mg} / \mathrm{g}$ dry weight. These results are in agreement with the previous study reported by Rupasinghe et al in $\mathbf{2 0 0 3}$ in which the concentration of saponin in soya bean was $15.6 \mathrm{mg} / \mathrm{g}$ dry weight in three different cultivars of soya bean by using reverse-phase high performance liquid chromatography (RPHPLC) with external standards.

The unique chemical structure of saponins is related to their hemolytic effects. Pore formation and cell permeabilization of saponins is due to the presence of cholesterol on the target membrane that is essential for the pore formation by interacting with saponins to form micelle-like complex and the hydrophilic sugar moieties are thought to be located in the central of the complex and leads to the development of aqueous pores. Such pores can increase the permeability of membrane and enabling the macromolecules and ions to pass through the membrane bilayer. This pore formation cause alteration of negatively charged carbohydrate portions on the erythrocyte cell surface which lead to lyse erythrocyte. Complexity of sugar moiety and the number of side chain in saponin have influenced hemolytic activity (Keukens et al., 1995 and Man et al., 2010).

In this study, the hemolytic activity of saponin was evaluated on human blood erythrocyte and the results showed that the hemolytic percents of red blood cell treated with soybean saponin was $50 \%$ at a concentration $417.73 \mu \mathrm{g} / \mathrm{ml}$. These results are agree with (Amini et al., 2014) and (Mozhgan et al., 2014) when they evaluated the hemolytic activity of saponin like compounds isolated from Persian Gulf brittle star (Ophiocoma erinaceus) and purified saponin from Holothuria leucospilota sea cucumber on human blood erythrocyte, who found that $\mathrm{HD}_{50}$ value was $500 \mu \mathrm{g} / \mathrm{ml}$ that indicated for high hemolytic activity. Therefore, Sun. (2008) assessed hemolytic activitiy of saponins isolated from the rhizoma of Anemone raddeana and demonstrated that saponins extracted exhibited a low hemolytic effect, with $16.50 \%$ and $3.56 \%$ at the concentrations of 500 and $250 \mu \mathrm{g} / \mathrm{ml}$, respectively (Sun et al., 2008). 
Due to the increasing attention paid to the cancer prevention, the term "chemoprevention" has made a career in scientific community (Steward and Brown, 2013). Some edible plants have been shown to reduce the risk of various types of cancer in humans (Ting $\boldsymbol{e t}$ al., 2014). Epidemiological data suggest that the risk of cancer rates are lower in the populations consuming the products largely of "natural" origin (unprocessed) (Saxe et al., 2008).

In this study, the antitumor activity of standard saponin and soybean saponin on colon cancer cells in vitro was evaluated by using MTT cytotoxicity assay. The results of the present study demonstrated that standard saponin and soybean saponin are cytotoxic to human colon cancer cells in which they decreased the viability of Coca cells in a dose dependant manner after $48 \mathrm{hr}$ treatment with $\mathrm{IC}_{50}$ value 28.7 and $43.4 \mu \mathrm{g} / \mathrm{ml}$ respectively. Other study showed that crude saponin isolated from Platycodi Radix induce apoptosis in HT29 colon cancer cell line with $\mathrm{IC}_{50}$ value $37.07 \mu \mathrm{g} / \mathrm{ml}$ in 24h treatment (Kim et al., 2008).

Also in this regard, saponins isolated from Solanum trilobatum leaf is preferentially cytotoxic to human larynx carcinoma cells in a dose dependent manner with $\mathrm{IC}_{50}$ value of $1 \mathrm{mg} / \mathrm{ml}$ after $24 \mathrm{hr}$ treatment (Kanchana and Balakrishna, 2011). Moreover, Lu et al. (2011) found that the viability of human breast cancer cells (MCF-7) was decreased when Rhizoma Paridis saponins concentration was raised in a dosedependent manner with $\mathrm{IC}_{50}$ value of $71.2 \mu \mathrm{g} / \mathrm{ml}$ after $48 \mathrm{hr}$ treatment.

\section{Conclusion:}

Our data demonstrated presence of saponin in legumes with high concentration in soybean and indicated that with comparation to above research reports saponin extracted from soybean exhibited hemolytic and cytotoxic activity on colon cancer cells in vitro. Based on these findings, for clinical application saponin isolated from soybean must be examined as anticancer chemopreventive drug against colon cancer cells in vivo.

\section{References}

Adiukwu, P.C., Kayanja, F.I.B., Nambatya, G.K., Rugera, S., Ezeonwumelu, J.O.C., Tanayen, J.K., Murokore, B.J., Twikirize, O.,
Twinomujuni, S., Byamugisha, D. and Imanirampa, L. (2013): Antipyretic and antinociceptive properties of the aqueous extract and saponin from an edible vegetable: Vernonia amygdalina leaf. African Journal of food, agriculture, nutrition and development .13 (2): $7588-7606$.

Amini, E., Nabiuni, M., Baharara, J., Parivar, K. and Asili, J. (2014): Hemolytic and cytotoxic effects of saponin like compounds isolated from Persian Gulf brittle star (Ophiocoma erinaceus). Journal of Coastal Life Medicine. 2(10): 762768.

Bachran, C., Bachran, S., Sutherland, M., Bachran, D. and Fuchs, H. (2008): Saponins in tumor therapy. Mini Rev Med Chem. 8(6):575-584.

Friess, S.L., Standaer, F.G., Whitcomb, E.R., Nigrelli, R.F., Chanley, J.D. and Sobotka, H. (1960): Some pharmacologic properties of holothurin A, a glycosidic mixture from the sea cucumber. Ann N Y Acad Sci. 90:893-901.

Gepdiremen, A., Mshvildadze, V., Suleyman, H. and Elias, R. (2005): Acute anti inflammatory activity of four saponins isolated from Ivy: alphahederin, hederasaponin-C, hederacolchiside-E and hederacolchiside- $F$ in carrageenan induced rat paw oedema. Phytomedicine. 12(6):440 - 444

Hassan, S.M., Haq, A.U., Byrd, J.A., Berhow, M.A., Cartwright, A.L. and Bailey, C.A. (2010): Haemolytic and antimicrobial activities of saponin-rich extracts from guar meal. Food Chem 2010; 119(2): 600-605.

Hu, J., Lee, S.O., Hendrich, S. and Murphy, P.A. (2002): Quantification of the Group B Soyasaponins by High-Performance Liquid Chromatography. J Agric Food Chem. 50(9):2587-94

Jamuna, S. and Subramanium, P. (2014): Thin layer chromatographic analysis for various secondary metabolites in the methanolic leaf and root extracts of Hypochaeris radicata L. Am. J. PharmTech Res.4 (2):2249-3387. 
Kanchana, A. and Balakrishna, M. (2011): Anti-cancer effects of saponins isolated from solanum trilobatum leaf extract and induction of apoptosis in human larynx cancer cell lines. Int J Pharm Pharm Sci. 3 (4):356-364.

Kareru, P.G., Keriko, J.M., Gachanja, A.N. and Kenji, G.M. (2008): Direct detection of triterpenoid saponins in medicinal plants. Afr $\mathrm{J}$ Tradit Complement Altern Med. 5(1): 56-60.

Kerem, Z., German-Shashoua, H.and Yarden, O. (2005): Microwave-assisted extraction of bioactive saponins from chickpea (Cicer arietinum $L$ ). Journal of the Science of Food and Agriculture. 85:406-412.

Keukens, E.A., de Vrije, T., van den Boom, C., de Waard, P., Plasman, H.H., Thiel, F., Chupin, V., Jongen, W.M. and de Kruijff, B. (1995): Molecular basis of glycoalkaloid induced membrane disruption. Biochim Biophys Acta.1240 (2):216-228.

Khalil, A.H. and El-Adawy, T.A. (1994):Isolation, identification and toxicity of saponin from different legumes. Food Chemistry.50:197-201.

Kim, M.O., Moon, D.O., Choi, Y.H., Lee, J.D., Kim, N.D. and Kim, G.Y. (2008): Platycodin D induces mitotic arrest in vitro, leading to endoreduplication, inhibition of proliferation and apoptosis in leukemia cells. Int $\mathrm{J}$ Cancer. 122 (12): 2674-2681.

Lu, C., Li, C.J., Wu, D., Lu, J.M., Tu, F. and Wang, L. (2011): Induction of apoptosis by Rhizoma Paridis saponins in MCF-7 human breast cancer cells. Afr J Pharm Pharmacol. 5(8): 1086-1091.

Man, S., Gao, W., Zhang, Y., Huang, L. and Liu, C. (2010): Chemical study and medical application of saponins as anti-cancer agents. Fitoterapia. 81: 703-714.

Messina, M.J. and Barnes, S. (1991): The role of soy products in reducing risk of cancer. J Natl Cancer Inst.83:541-546.

Mozhgan, S., Kazem P., Javad B., Mohammad, A. K.and Javad, A. (2014) Hemolytic and cytotoxic properties of saponin purified from Holothuria leucospilota sea cucumber. Rep. Biochem. Mol. Biol. 3:1-8.

Murakami, A.N., Amboni, R.D., Prudêncio, E.S., Amante, $\quad$ E.R., Fritzen-Freire, C.B., Boaventura, B.C., Muñoz Ide, B., Branco Cdos, S., Salvador, M. and Maraschin, M. (2013): Concentration of biologically active compounds extracted from Ilex paraguariensis St. Hil. By nanofiltration. Food Chem. 141 (1): 60-65.

Newman, D.J., Cragg, G.M and Snader, K.M. (2002): Natural products as sources of new drugs over the period 1981-2002. J Nat Prod.66:1022-1037

Pasaribu, T., Astuti, D.A., Wina, E., Sumiati. and Setiyono, A. (2014): Saponin Content of Sapindus rarak Pericarp Affected by Particle Size and Type of Solvent, its Biological Activity on Eimeria tenella Oocysts. Inter J Poultry Sci. 13(6):347-352.

Payal R. D., Vikram, S. T. and Chakraborthy, G.S. (2010): Evaluation of crude saponins extract from leaves of Sesbania sesban (L.) Merr. for topical anti-inflammatory activity. Int. J. Res. Pharm. Sci. 1(3):296-299.

Phillipson, J. D. (2001): Phytochemistry and medicinal plants. Phytochemistry, 56: 237-243.

Ranjith, R. K., Kranti, S. Mulpuri. and Bharathi, M. (2014): Advancements in column chromatography: A review. World Journal of Pharmaceutical Sciences. 2321-3086.

Rupasinghe, H.P., Jackson, C.J., Poysa, V., Di Berardo, C., Bewley, J.D. and Jenkinson, J. (2003): Soyasapogenol A and B distribution in soybean (Glycine max L. Merr.) in relation to seed physiology, genetic variability and growing location. J Agric Food Chem. 51 (20): 58885894.

Saxe, G.A., Major, J.M., Westerberg, L., Khandrika, S. and Downs, T.M. (2008): Biological mediators of effect of diet and stress reduction on prostate cancer. Integr Cancer Ther. 7 (3): 130-138. 
Silchenko, A.S., Avilov, S.A., Kalinin, V.I., Kalinovsky, A.I., Dmitrenok, P.S., Fedorov, S.N.,Stepanov,V.G.,Dong, Z. and Stonik,V.A. (2008): Constituents of the Sea Cucumber Cucumaria okhotensis. Structures of Okhotosides B1-B3 and Cytotoxic activities of Some Glycosides from this Species $\perp$. J Nat Prod. Feb; 71(3):351-6.

Snyder, L. R., Kirkland, J. J. and Glajch, J. L. (1997): Practical HPLC Method DeVelopment, 2nd ed., Wiley: New York, 210-224.

Soltani, M., Parivar, K., Baharara, J., Kerachian, M.A. and Asili, J. (2014): Hemolytic and cytotoxic properties of saponin purified from Holothuria leucospilota sea cucumber. Rep. Biochem. Mol. Biol. 3 (1):43-50.

Sottorff, I., Aballay, A., Hernández, V., Roa, L., Muñoz, L.X. and Silva, M. (2013): Characterization of bioactive molecules isolated from sea cucumber Athyonidium chilensis. Rev biol mar oceanogr. 48(1):23-35.

Steward, W.P. and Brown, K. (2013): Cancer chemoprevention: a rapidly evolving field. $\mathrm{Br} \mathrm{J}$ Cancer. 109 (1): 1-7.

Sun, Y., Li, M. and Liu, J. (2008): Haemolytic activities and adjuvant effect of Anemone raddeana saponins (ARS) on the immune responses to ovalbumin in mice. Int Immunopharmacol. 8 (8): 1095-1102.

Tani, T., Katsuki, T., Kubo, M., Arichi, S. and Kitagawa, I. (1985): Histochemistry V. Soyasaponins in soybeans (Glycine max, Merrill, seeds). Chem Pharm Bu1.33: 38293833.
Ting, H., Deep, G., Agarwal, C. and Agarwal, R. (2014): The strategies to control prostate cancer by chemoprevention approaches. Mutation Res. 760: $1-15$.

Xiang, Z. B., Tang, C. H., Chen, G. and Shi, Y. S. (2001): Studies on colorimetric determination of oleanolic acid in Chinese quince. Nat Prod Res Develop 13(4): 2326.

Yoko, U., Keiko, H. and Kazuo, S. (2000): Spectrophotometric Determination of Saponin in Yucca Extract Used as Food Additive. Journal Of AOAC INTERNATIONAL.83:1451-1454.

Zahra, B. and Parvin, M. (2015): Potential properties of legumes as important functional foods for management of type 2 diabetes. International Journal of Nutrition and Food Sciences. 4(2-1): 6-9.

Zhang, W. and Popovich, D. G. (2008): Effect of soyasapogenol A and soyasapogenol B concentrated extracts on Hep-G2 cell proliferation and apoptosis. J. Agric. Food Chem. 56 (8): 2603-2608.

Zhao, H.L., Harding, S.V., Marinangeli, C.P., Kim, Y.S. and Jones, P.J. (2008): Hypocholesterolemic and anti-obesity effects of saponins from Platycodon grandiflorum in hamsters fed atherogenic diets. J Food Sci . 73 (8): H195 - 200.

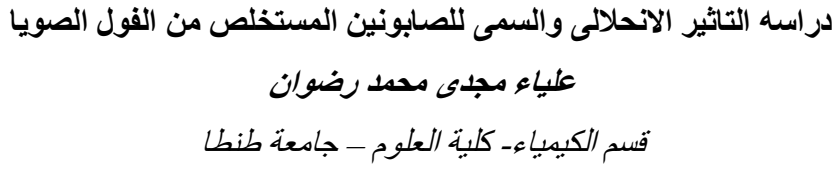

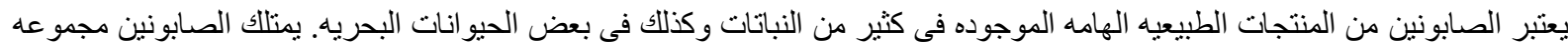

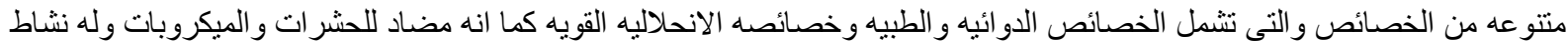

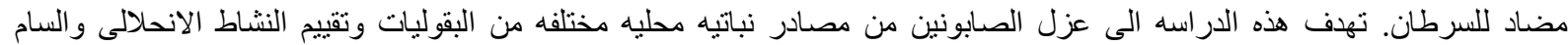
للصابونين الموجود فى اعلى مصدر. فى هذه الدر اسه نم استخلاص الصنابونين من البقوليات باستخدام الكلوروفورم و الايثانول. الصابونين 


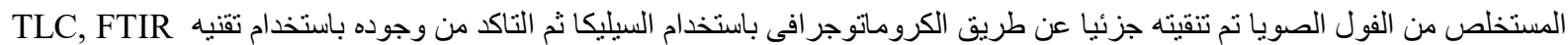
و

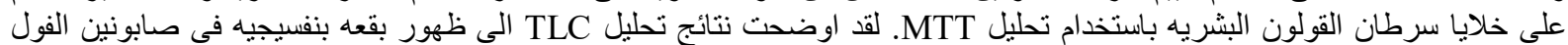

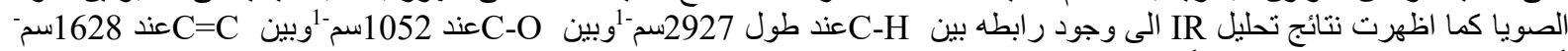

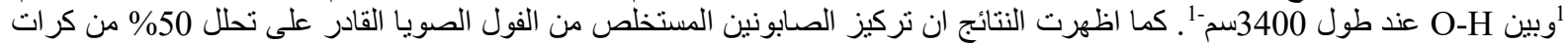

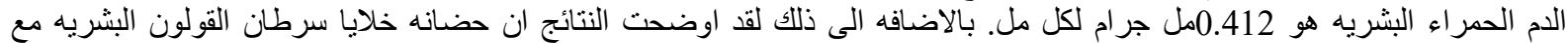

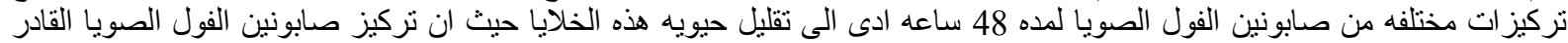

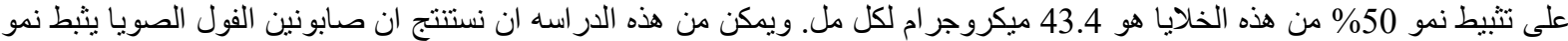
خلايا سرطان القولون لذلك من الممكن ان يكون له تطبيقات علاجيه فى المستقبل. 